\title{
Antimalarial and Antiviral Drugs: A Review of Trials and Effectivenessin Treating COVID-19
}

\section{Chandra Adwani}

Medical Intern, Department of Community Medicine, Jawaharlal Nehru Medical College, Datta Meghe Institute of Medical Sciences (DMIMS), Sawangi (M), Wardha-442004, Maharashtra, India.

Corresponding author email: adwanichandra@rediffmail.com

\section{ABSTRACT}

The first case of COVID-19 in China was identified on December 1, 2019. It was reported to WHO on December 31, 2019. Now COVID-19 has turned into one of the greatest health disasters and is declared as a pandemic and a global threat by World Health Organization on January 30, 2020. COVID-19 was declared as global pandemic on March 11, 2020. COVID-19 is a pathogenic viral infection which easily transmits through respiratory droplets and transmitted through their contact instead of air transmission. It is considered most contagious when people are symptomatic, although transmission is possible before symptom. With the increase in number of cases of infected patients and rise in mortality rates, there weren't any definitive curative or preventive guidelines for physician to challenge this virus. Use of antiviral, immunotherapies, vaccines and other effective therapies are being investigated in different stages for evaluation of COVID-19. Trials of a number of drugs including remdesvir, ivermectin, hydoxychloroquine, chloroquine, favipiravir, merimepodib and lopinavir were reported. This review attempted to compile the outcomes and future research needs of these trials.

KEY WORDS: COVID-19, ANTIVIRAL DRUGS, ANTIMALARIALS, REMDESVIR, IVERMECTIN, HYDOXYCHLOROQUINE, FAVIPIRAVIR, MERIMEPODIB, LOPINAVIR.

\section{INTRODUCTION}

SARS-CoV-2(Severe acute respiratory syndrome) formerly known as 2019-nCoV (novel corona virus) causes coronavirus disease 2019 (COVID-19).It belongs to family of viruses known as Coronaviridae, subfamily Coronavirinae and the order Nidovirales.It is a respiratory illness identified amid outbreak in Hunan seafood market at Wuhan City, Hubei Province,China (Paules CI, et al 2020). The first case in China was identified on December 1, 2019. It was reported to WHO on December 31, 2019. Now COVID-19 has turned into one of the greatest health disasters and is declared as a pandemic and a

Biosc Biotech Res Comm P-ISSN: 0974-6455 E-ISSN: 2321-4007

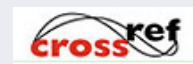

Identifiers and Pagination

Year: 2021 Vol: 14 No (6) Special Issue

Pages: 231-236

This is an open access article under Creative

Commons License Attribn 4.0 Intl (CC-BY).

DOI: $h t t p: / / d x . d o i . o r g / 10.21786 / b b r c / 14.6 .48$ global threat by World Health Organization on January 30, 2020. COVID-19 was declared as global pandemic on March 11, 2020 (Zhu H et al 2020).

COVID-19 is a pathogenic viral infection which easily transmits through respiratory droplets and transmitted through their contact instead of air transmission. symptomatic, although transmission is possible before symptom. With the increase in number of cases of infected patients and rise in mortality rates, there weren't any definitive curative or preventive guidelines for physician to challenge this virus. Use of antiviral, immunotherapies, vaccines and other effective therapies are being investigated in differentstages for evaluation of COVID19 (Dhama K, et al 2020). In vitro and in vivo clinical trials of some of the most frequently used antiviral drugs which are commonly being used all over the world against SARS-CoV-2 are reviewed in this article. Trials of drugs reviewed are remdesvir, ivermectin, hydoxychloroquine, chloroquine, favipiravir, merimepodib and lopinavir/ It is considered most contagious when people are

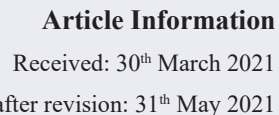

ccepted after revision: $31^{\text {th }}$ May 2021 
ritonavir. Evidences and early results obtained from the interventional trials of these antiviral drugs are summarized.

\section{METHODS}

A literature review was carried out using Google Scholar to identify many relevant research articles which were published through June 14, 2020. Key words used as search terms were coronavirus, COVID-19 and SARSCoV-2 in combination with treatment and pharmacology. Titles and abstracts of the research articles were reviewed independently for inclusion. Some of the research articles were used to identify other relevant articles.

Remdesivir: Remdesvir is adenosine nucleotide analogue. It is a prodrug metabolized intracellularly inhibiting viral RNA polymerases. It acts against virus families like flavoviruses, coronaviruses and Middle East respiratory syndrome (MERSCoV). Improvement with use of remdesvir was initially seen in COVID-19 patients in US and after that trial was assessed to test effectiveness and safety of given drug in hospitalized COVID-19 patients. In a cohort of patient receiving remdesivir for treatment of COVID-19, 36 patients out of 53 patients showed improvement (Grein J, et al 2020). But there was no concrete conclusion to this trial because of absence of no comparator or placebo in this study.

A Placebo controlled double blinded randomized trial of intravenous remdesivir was conducted in COVID-19 hospitalized adult ( $\geq 18$ years) patients with SARS-CoV-2 infection. On day 1, 158 patienta were given $200 \mathrm{mg}$ dose intravenous remdesivir. Dose of $100 \mathrm{mg}$ was given daily for next 2 to 10 days daily. Same volume of placebo was given to 79 patients. Concomitant use of lopinavirritonavir, corticosteroids and interferon was permitted.In this study there wasn't significant clinical improvement with difference in time seen in patient on remdesivir. $102(66 \%)$ of 155 remdesivir recipients showed adverse effects compared to 50(64\%) of 78 placebo recipients. It was found that there was no significant improvement with the use of remdesivir over placebo (Wang Y, et al 2020).

Another placebo controlled, double blinded randomized trial of intravenous remdesivir was conducted in adult patients with lower respiratory tract infection. Out of 1059 patient undergoing randomization, 538 were assigned with remdesivir and remaining 521 were given placebo. Patients randomly received a loading dose of $200 \mathrm{mg}$ of remdesivir or placebo on day 1. Additionally dose of $100 \mathrm{mg}$ was given daily for following 9 days. Data after randomized trial showed the recovery time of 11 days in patient receiving remdesivir and those receiving placebo showed recovery time of 15 days. 21.1 per cent patient noted with adverse events receiving remdesivir and 27 per cent in patient with placebo. Remdesivir was found out to be superior to placebo to shorten the time of recovery of adult patients with lower respiratory tract infection (Beigel JH. Et al 2020).
Ivermectin: Ivermectin is originally a broad spectrum anti parasitic drug approved by FDA but in recent years its broad range anti-viral effect has been identified. It limits infection against RNA viruses. In vitro activity of ivermectin was studied against SARS-CoV-2 in Vero/ hSLAM cells. Vero/hSLAM cells were infected with the virus. After $2 \mathrm{~h}$ of infection ivermectin $(5 \mu \mathrm{M})$ was added and was allowed to incubate for 0-3 days. Samples (cell supernatant) were taken at appropriate time point after infection of cells to check the viral load. Triplicate real time PCR was performed on sample (supernatant) using probe against SARS-CoV-2 or RdRp gene. After $24 \mathrm{~h}$ of infection there was 93 per cent reduction in viral load of cells treated with ivermectin. Reduction in viral RNA was observed to be $~ 5000$ fold at $48 \mathrm{~h}$. No ivermectin associated toxicity was observed at any time during observation (Caly L, et al 2020). According to the author, further clinical trials were recommended.

Another study was carried out to evaluate the dose prediction of ivermectin in humans to reach the half maximal inhibitory concentration $\left(\mathrm{IC}_{50}\right)$ in the lungs to design a successful clinical trial. Simulations were conducted using pharmacokinetic model which was built on subjects given ivermectin with high fat breakfast. Since ivermectin is taken empty stomach, corrections were provided. It was found out that ivermectin is not likely to reach $\mathrm{IC}_{50}$ in the lungs even with the approved dose. Doses ten times higher than approved also failed to show promising results. Probability of success of ivermectin with approved dose against COVID-19 was found out to be low (Schmith VD, et al 2020).

Hydroxychloroquine and Chloroquine: Hydroxychloroquine (HCQ) and chloroquine (CQ) belong to aminoquinoline group of drug which is used to treat malaria and some autoimmune diseases. HCQ and CQ inhibit the immune activation by interfering with production of various proinflammatory cytokine IL-1, INF-alfa, TNF. HCQ and CQ also changes pH concentration and cyclic GMP0-AMP (cGMP) synthase activity. HCQ and CQ also interfere with activity of Toll like receptor (TLR7 and TLR9) by inhibiting the signaling pathway (Schrezenmeie E, et al 2020). CQ acts as a weak diprotic base. It can penetrate organelle with acid nature like lysosome which result in increasing $\mathrm{pH}$ of organelle and thus preventing endosome trafficking. This also helps in viral fusion into cell.

Even though the use of HCQ and CQ in the treatment guideline of COVID-19 was followed all over the world but the details regarding the drug usage is quite frightening. There is no primary detail supporting HCQ and CQ in decreasing the disease progress or reducing the duration of COVID-19 as early report from China supporting these. A randomized trial was conducted which included 30 patients of coronavirus disease. Out of this 15 patients were administered 400mg HCQ supported with conventional treatment. Other 15 patients were only on conventional management. With this the concrete line of conclusion couldn't be drawn between the above two groups for mean clearance time for virus, temperature 
normalization and the amount of viral clearance from nasopharynx on day 7 (Chen J, et al 2020).

Another study of 36 adults (18yr) with coronavirus disease was done. It was an open label case control study type of study. It was noted that the SARS-CoV 19 RNA on specimen taken from nasopharynx at day 6 of treatment was less detectable in patients on HCQ (200 mg 3times a day taking for 10 days) when compared to patients receiving no particular treatment. But the outcome of use of HCQ in combination with Azithromycin (belonging to a macrolide class of drug) was $100 \%$ clearance rate when compared to the use of HCQ alone which resulted in $57 \%$ clearance of virus from nasopharynx (Gautret $\mathrm{P}$, et al 2020).

The group who did study of the above trial published the outcome of 80 coronavirus disease patients who were given the combination HCQ with Azithromycin (macrolide). The improvement was seen in all the patients except 2 patients, an 86 year old patient died and a 74 year old patient was in ICU for longer time. The nasopharyngeal samples were cultured on day 5 of treatment which showed negative in 97.5 per cent patients. qPCR was done on sample taken from nasopharynx to check for the viral load which showed 83 per cent negative on day 7 and a reduction if 93 per cent of viral load on day 8 (Gautret P, et al 2020). Based on the above studies there have been adoption of HCQ and CQ regimen for COVID-19 treatment by the clinicians worldwide. The drugs HCQ and CQ both are involved in increasing the risk for sudden cardiac death, drug induced torsade's de pointes, QT interval prolongation.

The safety and efficacy of CQ was tested on QT interval with two different doses of CQ. Randomized, double blinded phase IIb trial was done in hospitalized COVID patients. The patients with high dose CQ showed QTc $>500$ ms (25\%) with high mortality than the low dosage CQ. Therefore high dosage CQ should not be recommended for treating COVID-19 patients (Kezerashvili A et al 2007). In another study done in USA for effect of CQ on QT interval, 84 patients (adults) infected with SARS-CoV-2 were treated with combination of HCQ and azithromycin (marcolide). Prolongation of QTc was maximum between days 3 and 4. More than $40 \mathrm{~ms}$ increase in QTc was seen in 30 per cent patients while 11 per cent patients showed $>500$ ms QTc prolongation which represent patients with increased risk for arrhythmia (Borba MGS, et al 2020).

Preventive action of HCQ or CQ against viral fusion and entry into cell were the reasons these two drugs were recommended for prophylactic use in pandemic of coronavirus. But due to lack of details to support this recommendation HCQ or CQ should not be used aspreventive measures against SARS-CoV-2. There is no clear detail regarding role of HCQ or CQ in treatment and prophylaxis. Also it has risk of cardiac toxicity and arrhythmia (Barlow A, et al 2020).

Favipiravir: Favipiravir (6-fluoro-3-hydroxy-2pyrazinecarboxamide) has an antiviral property against
RNA virus. RNA-dependent RNA polymerase (RdRp) acts on intracellular activated form of flavipiravir, thus inhibiting the RNA polymerase activity. The known action of flavipiravir is found to be against RNA viruses like influenza, arenavirus, bunyavirus, flavivirus, filoviruses causing hemorrhagic fevers, Ebola virus. As corona virus contain single stranded RNA virus, flavipiravir is supposed to have an inhibitory action against coronavirus.

In a study of 80 lab confirmed corona virus infected adult patients two groups were made. One arm of 35 patients administered with oral flavipiravir $(1600 \mathrm{mg}$ 2 times a day followed by $600 \mathrm{mg} 2$ times a day for next 2-14 days) along with interferon alfa (aerosol) inhalational another arm of 45 patients were given oral lopinavir/ritonavir $(400 \mathrm{mg} / 100 \mathrm{mg} 2$ times a day for 14 days) along with interferon alfa in aerosol inhalation form. The two arms were compared on basis of viral clearance, chest radiograph and safety. Favipiravir was found to be better than the control drug in terms of viral clearance, improvement in chest radiograph. Some of the adverse effect was seen with flavipiravir but lesser than the control arm drug (Cai Q, et al 2020).

Another trial conducted with 240 mild-moderate affected patients in which 120 patients were administered with flavipiravir and another 120 patients were given arbidol. Comparison was done on the basis of clinical improvement (fever and cough) of 7 days. Recovery rate in flavipiravir treated patient was found to be 71.43 per cent whereas in arbidol recovery rate was 55.86 per cent. The adverse effects which can occur with flavipiravir are abnormal liver function test, psychiatric symptoms, GIT dysfunction (Chen C, et al 2020).The above study data is insufficient for use of flavipiravir in treatment of COVID-19.

Merimepodib: Merimepodib is an investigational antiviral drug which act as a non competitive inhibitor of IMPDH .This drug is already being tested against many RNA viruses like hepatitis C, zika, ebola, lassa, junin and chikungunya viruses. In vitro suppression of SARS-CoV-2 replication by merimepodib is studied by pretreatment of cell with merimepodib. Once the vero cells were pretreated with merimepodib before infection and kept overnight for another time vero cells were again treated with merimepodib before infection for 4 hours. There was a reduction of 4 logs of magnitude in overnight treated cells and 3 log drop was observed in 4 hour prior treated cells.

This study provided evidence of virus penetrating the uninfected cells and thereby decreasing the viral load after infection. Therefore this drug can be used to reduce chance of viral spread from nasopharynx to lungs. As large population has been exposed due to pandemic to this highly contagious coronavirus the use of merimepodib can be done as prophylactic drug. Merimepodib can also be used in asymptomatic laboratory confirmed corona infected patients to eliminate the nascent infection (Bukreyeva $\mathrm{N}$ et al 2020). Merimepodib can be a viable 
drug in treatment of COVID-19 patients along with other potent antiviral and immunomodulator drugs.

Lopinavir/Ritonavir (LPV/r): Lopinavir is used along with ritonavir in treatment of HIV. Lopinavir act as a protease inhibitor and ritonavir as a booster. Protease enzyme processes polyprotein in coronavirus. Many in vitro studies showed Lopinavir has inhibitory action against SARS-CoV-2 infected Vero E6 cells. In a cohort study of COVID-19 patient group of patients treated with LPV/r combined with ribavirin and another group with ribavirin alone. Risk of acute respiratory distress syndrome (ARDS) or death due to SARS-CoV was lower in lopinavir/ritonavir plus ribavirin treated patient (2.4\%) than ribavirin alone treated patients (28.8\%). Lopinavir/ ritonavir when given in early stages has better clinical result (Chu CM, et al 2004).

A randomized, controlled and open label trial was conducted with COVID-19 hospitalized adult (>18yr). A total of 199 patients were selected out of which 99 were given LPV/r and other 100 were given standard care post randomization. There was no significant difference between both the groups in terms of clinical improvement. The GIT adverse events were associated with LPV/r group but the serious adverse events were associated with standard care group (Cao B, et al 2020). Another study of randomized controlled trial of 3 groups was done. The groups were randomly assigned 21 patients receiving $\mathrm{LPV} / \mathrm{r}, 16$ patients with arbidol and remaining 7 patients with no antiviral medication. No difference was observed in improvement of fever or cough, chest radiograph (Li Y, et al 2020). With the above study it is arduous to find if LPV/r has its role in treating COVID-19 patients. GIT dysfunctions like nausea, vomiting, diarrhea etc. require close monitoring during LPV/r trial.

Cardiovascular morbidities have been reported to be major factor in deaths due to Covid-19. Use of drugs like Alirocumab (Bittner, et al 2020, Goodman, et al 2019, Jukema, J. et al 2019, Ray, et al 2019, Steg,et al 2019 and White, Harvey D.,et al 2019) for preventing deaths in patients with pre-existing cardiovascular morbidities may be useful. A number of studies on related aspects of Covid-19 were reported (Jaiswal, A., et al 2020, Jameel, P.Z., et al 2020, Jilte, A.A., and M.A. Deshpande. 2020, Joseph, M.B., et al 2020, Kalagani, B., et al 2020 and Nibudey, A., and S. Vidya Baliga 2020). (Khubchandani et. al. 2020) discussed emerging therapeutic options for COVID. (Kute et.al. 2020) reflected on NOTTO transplant specific guidelines with reference to COVID. (Pate et.al. 2020) discussed on Best Practices for Endoscopic Procedures in Covid-19 Pandemic.

\section{CONCLUSION}

The COVID-19 pandemic has proven itself to be the greatest global public health disaster since the influenza pandemic of 1918. Although clinical trials of antiviral drugs are being carried out at high pace and great volume, currently there no antiviral drugs which are proven fully verified to be effective against SARS-CoV-2.

\section{ACKNOWLEDGEMENTS}

Author appreciates Sarthak Bisen for his help in reviewing and editing the manuscript.

Funding: DMIMS, Wardha.

Conflict of Interest: Author has no conflict of interest to declare.

\section{REFERENCES}

Beigel, J.H., Tomashek, K.M., Dodd, L.E., Mehta, A.K., Zingman, B.S., Kalil, A.C., Hohmann, E., Chu, H.Y., Luetkemeyer, A., Kline, S. and Lopez de Castilla, D., 2020. Remdesivir for the treatment of Covid-19. New England Journal of Medicine, 383(19), pp.1813-1826. Bittner, V.A., Szarek, M., Aylward, P.E., Bhatt, D.L., Diaz, R., Edelberg, J.M., Fras, Z., Goodman, S.G., Halvorsen, S., Hanotin, C. and Harrington, R.A., 2020. Effect of alirocumab on lipoprotein (a) and cardiovascular risk after acute coronary syndrome. Journal of the American College of Cardiology, 75(2), pp.133-144.

Balibrea, J.M., Badia, J.M., Pérez, I.R., Antona, E.M., Peña, E.Á., Botella, S.G., Gallego, M.Á., Pérez, E.M., Cortijo, S.M., Miguelañez, I.P. and Díaz, L.P., 2020. Surgical management of patients with COVID-19 infection. Recommendations of the Spanish Association of Surgeons. Cirugía Española (English Edition), 98(5), pp.251-259.

Borba, M.G.S., Val, F.F.A., Sampaio, V.S., Alexandre, M.A.A., Melo, G.C., Brito, M., Mourão, M.P.G., BritoSousa, J.D., Baía-da-Silva, D., Guerra, M.V.F. and Hajjar, L.A., 2020. Effect of high vs low doses of chloroquine diphosphate as adjunctive therapy for patients hospitalized with severe acute respiratory syndrome coronavirus 2 (SARS-CoV-2) infection: a randomized clinical trial. JAMA network open, 3(4), pp.e208857e208857.

Barlow, A., Landolf, K.M., Barlow, B., Yeung, S.Y.A., Heavner, J.J., Claassen, C.W. and Heavner, M.S., 2020. Review of emerging pharmacotherapy for the treatment of coronavirus disease 2019. Pharmacotherapy: The Journal of Human Pharmacology and Drug Therapy, 40(5), pp.416-437.

Bukreyeva, N., Mantlo, E.K., Sattler, R.A., Huang, C., Paessler, S. and Zeldis, J., 2020. The IMPDH inhibitor merimepodib suppresses SARS-CoV-2 replication in vitro. bioRxiv.

Cai, Q., Yang, M., Liu, D., Chen, J., Shu, D., Xia, J., Liao, X., Gu, Y., Cai, Q., Yang, Y. and Shen, C., 2020. Experimental treatment with favipiravir for COVID19: an open-label control study. Engineering, 6(10), pp.1192-1198.

Caly, L., Druce, J.D., Catton, M.G., Jans, D.A. and 
Wagstaff, K.M., 2020. The FDA-approved drug ivermectin inhibits the replication of SARS-CoV-2 in vitro. Antiviral research, 178, p.104787.

Cao, B., Wang, Y., Wen, D., Liu, W., Wang, J., Fan, G., Ruan, L., Song, B., Cai, Y., Wei, M. and Li, X., 2020. A trial of lopinavir-ritonavir in adults hospitalized with severe Covid-19. New England Journal of Medicine. Chen, J., Liu, D., Liu, L., Liu, P., Xu, Q., Xia, L., Ling, Y., Huang, D., Song, S., Zhang, D. and Qian, Z., 2020. A pilot study of hydroxychloroquine in treatment of patients with common coronavirus disease-19 (COVID19). Journal of Zhejiang University (Medical Science), 49(1), pp.0-0.

Chen, C., Huang, J., Cheng, Z., Wu, J., Chen, S., Zhang, Y., Chen, B., Lu, M., Luo, Y., Zhang, J. and Yin, P., 2020. Favipiravir versus arbidol for COVID-19: a randomized clinical trial. MedRxiv.

Chu, C.M., Cheng, V.C.C., Hung, I.F.N., Wong, M.M.L., Chan, K.H., Chan, K.S., Kao, R.Y.T., Poon, L.L.M., Wong, C.L.P., Guan, Y. and Peiris, J.S.M., 2004. Role of lopinavir/ritonavir in the treatment of SARS: initial virological and clinical findings. Thorax, 59(3), pp.252256.

Dhama, K., Sharun, K., Tiwari, R., Dadar, M., Malik, Y.S., Singh, K.P. and Chaicumpa, W., 2020. COVID19, an emerging coronavirus infection: advances and prospects in designing and developing vaccines, immunotherapeutics, and therapeutics. Human vaccines Et immunotherapeutics, 16(6), pp.1232-1238.

Gautret, P., Lagier, J.C., Parola, P., Meddeb, L., Mailhe, M., Doudier, B., Courjon, J., Giordanengo, V., Vieira, V.E., Dupont, H.T. and Honoré, S., 2020. Hydroxychloroquine and azithromycin as a treatment of COVID-19: results of an open-label non-randomized clinical trial. International journal of antimicrobial agents, 56(1), p.105949.

Gautret, P., Lagier, J.C., Parola, P., Meddeb, L., Sevestre, J., Mailhe, M., Doudier, B., Aubry, C., Amrane, S., Seng, P. and Hocquart, M., 2020. Clinical and microbiological effect of a combination of hydroxychloroquine and azithromycin in 80 COVID-19 patients with at least a six-day follow up: a pilot observational study. Travel medicine and infectious disease, 34, p.101663.

Goodman, S.G., Aylward, P.E., Szarek, M., Chumburidze, V., Bhatt, D.L., Bittner, V.A., Diaz, R., Edelberg, J.M., Hanotin, C., Harrington, R.A. and Jukema, J.W., 2019. Effects of alirocumab on cardiovascular events after coronary bypass surgery. Journal of the American College of Cardiology, 74(9), pp.1177-1186.

Grein, J., Ohmagari, N., Shin, D., Diaz, G., Asperges, E., Castagna, A., Feldt, T., Green, G., Green, M.L., Lescure, F.X. and Nicastri, E., 2020. Compassionate use of remdesivir for patients with severe Covid-19. New
England Journal of Medicine, 382(24), pp.2327-2336. Jameel, P.Z. and Taksande, A.M., 2020. COVID-19: A review of drugs and therapies for children. Sri Lanka Journal of Child Health, 49(3), pp.210-217..

Jilte, A.A. and Deshpande, M.A., 2020. Role of rasayana (Kutipraveshik rasayana and achar rasayana) in the prevention of covid 19 like new diseases. International Journal of Research in Pharmaceutical Sciences, 11(Special Issue 1).

Joseph, M.B., Pohekar, S., Raut, A. and Patil, M., 2020. The palliative care and covid-19 pandemic. International Journal of Research in Pharmaceutical Sciences, 11(Special Issue 1).

Jukema, J.W., Szarek, M., Zijlstra, L.E., de Silva, H.A., Bhatt, D.L., Bittner, V.A., Diaz, R., Edelberg, J.M., Goodman, S.G., Hanotin, C. and Harrington, R.A., 2019. Alirocumab in patients with polyvascular disease and recent acute coronary syndrome: ODYSSEY OUTCOMES trial. Journal of the American College of Cardiology, 74(9), pp.1167-1176.

Kezerashvili, A., Khattak, H., Barsky, A., Nazari, R. and Fisher, J.D., 2007. Azithromycin as a cause of QT-interval prolongation and torsade de pointes in the absence of other known precipitating factors. Journal of Interventional Cardiac Electrophysiology, 18(3), pp.243-246.

Kute, V., Guleria, S., Prakash, J., Shroff, S., Prasad, N., Agarwal, S.K., Varughese, S., Gupta, S., Gokhale, A.G.K., Sahay, M. and Sharma, A., 2020. NOTTO transplant specific guidelines with reference to COVID-19. Indian Journal of Nephrology, 30(4), p.215.

Latchoumi, T.P., Ezhilarasi, T.P. and Balamurugan, K., 2019. Bio-inspired weighed quantum particle swarm optimization and smooth support vector machine ensembles for identification of abnormalities in medical data. SN Applied Sciences, 1(10), pp.1-10.

Li, Y., Xie, Z., Lin, W., Cai, W., Wen, C., Guan, Y., Mo, X., Wang, J., Wang, Y., Peng, P. and Chen, X., 2020. An exploratory randomized, controlled study on the efficacy and safety of lopinavir/ritonavir or arbidol treating adult patients hospitalized with mild/moderate COVID-19 (ELACOI). MedRxiv.

Nibudey, A. and Baliga, S.V., Preparing Hospitals in India for Covid-19 Pandemic. International Journal of Research in Pharmaceutical Sciences, 11, pp.333-41. Islam, M.T., Nasiruddin, M., Khan, I.N., Mishra, S.K., Kudrat-E-Zahan, M., Riaz, T.A., Ali, E.S., Rahman, M.S., Mubarak, M.S., Martorell, M. and Cho, W.C., 2020. A perspective on emerging therapeutic interventions for COVID-19. Frontiers in public health, 8.

Pate, B.S., Yeola, M.E., Gawande, A., Singh, A.K. and Tayade, H.A., 2020. Best Practices for Endoscopic Procedures in Covid-19 Pandemic. Journal of Evolution 
of Medical and Dental Sciences, 9(49), pp.3760-3767. Paules, C.I., Marston, H.D. and Fauci, A.S., 2020. Coronavirus infections-more than just the common cold. Jama, 323(8), pp.707-708.

Ray, K.K., Colhoun, H.M., Szarek, M., Baccara-Dinet, M., Bhatt, D.L., Bittner, V.A., Budaj, A.J., Diaz, R., Goodman, S.G., Hanotin, C. and Harrington, R.A., 2019. Effects of alirocumab on cardiovascular and metabolic outcomes after acute coronary syndrome in patients with or without diabetes: a prespecified analysis of the ODYSSEY OUTCOMES randomised controlled trial. The lancet Diabetes \&t endocrinology, 7(8), pp.618-628.

Sankar, J., Dhochak, N., Kabra, S.K. and Lodha, R., 2020. COVID-19 in children: clinical approach and management. The Indian Journal of Pediatrics, 87(6), pp.433-442.

Schmith, V.D., Zhou, J. and Lohmer, L.R., 2020. The approved dose of ivermectin alone is not the ideal dose for the treatment of COVID-19. Clinical Pharmacology Et Therapeutics, 108(4), pp.762-765.

Schrezenmeier, E. and Dörner, T., 2020. Mechanisms of action of hydroxychloroquine and chloroquine: implications for rheumatology. Nature Reviews Rheumatology, 16(3), pp.155-166.

Steg, P.G., Szarek, M., Bhatt, D.L., Bittner, V.A., Bregeault, M.F., Dalby, A.J., Diaz, R., Edelberg, J.M., Goodman, S.G., Hanotin, C. and Harrington, R.A., 2019. Effect of alirocumab on mortality after acute coronary syndromes: an analysis of the ODYSSEY OUTCOMES randomized clinical trial. Circulation, 140(2), pp.103112.

Wang, Y., Zhang, D., Du, G., Du, R., Zhao, J., Jin, Y., Fu, S., Gao, L., Cheng, Z., Lu, Q. and Hu, Y., 2020. Remdesivir in adults with severe COVID-19: a randomised, doubleblind, placebo-controlled, multicentre trial. The Lancet, 395(10236), pp.1569-1578.

White, H.D., Steg, P.G., Szarek, M., Bhatt, D.L., Bittner, V.A., Diaz, R., Edelberg, J.M., Erglis, A., Goodman, S.G., Hanotin, C. and Harrington, R.A., 2019. Effects of alirocumab on types of myocardial infarction: insights from the ODYSSEY OUTCOMES trial. European heart journal, 40(33), pp.2801-2809.

Zhu, H., Wei, L. and Niu, P., 2020. The novel coronavirus outbreak in Wuhan, China. Global health research and policy, 5(1), pp.1-3. 